\title{
AN EXTRUSIVE-PLUTONIC EVENT AT HARDY POINT AND ITS VICINITY- GREENWICH ISLAND - ANTARCTIC
}

\author{
DELIA DEL PILAR M. DE ALMEIDA ${ }^{1}$, ADRIANE MACHADO ${ }^{2}$, MARCOS A. F. HANSEN ${ }^{1}$, \\ HENRIQUE FENSTERSEIFER ${ }^{1}$, LARISSA DE LIMA ${ }^{1}$ AND CRISTIANE H. GOMES ${ }^{1}$
}

\begin{abstract}
The volcanic and intrusive rocks at Hardy Point and its vicinity were formed mainly during a Mesozoic magmatism. Andesiticbasalt flows and andesites constitute the volcanic rocks. The intrusive ones were expressed as an epizonal body, with dioritic to granitic composition, and are cogenetic to the volcanic ones. The geochemical patterns indicate that volcanism preceded plutonism. In rare earth elements diagram the intrusive rocks present a further developed pattern, in which all rocks show calc-alkaline affinity, an enrichment in light rare earth elements relative to the heavy ones, probably due to partial melting of the mantle. In the spidergram (LILE, HFSE) the same pattern is observed for all rock groups, with strong negative anomalies of $\mathrm{Ti}, \mathrm{P}$ and $\mathrm{Nb}$, typical of island arcs, besides a positive anomaly of Ce, which could be related to the assimilation of Ce-enriched marine sediments.
\end{abstract}

Keywords:

\section{INTRODUCTION}

Hardy Point and vicinity are located on Greenwich Island which is part of the South Shetland Islands, in Antarctica (Fig. 1). The area lies between parallels 62'32'30"; $62^{\circ} 34^{\prime} 00^{\prime \prime} \mathrm{S}$ and meridians, 59 $32^{\prime} 30^{\prime \prime} ; 59^{\circ} 37^{\prime} 30^{\prime \prime} \mathrm{W}$. The zone has an area of approximately 15 square $\mathrm{km}$.

Fourteen assays of major elements, trace and rare earth elements were performed at the Activation Laboratories LTD-ACTLABS (Canada), using the argon plasma spectrometry-ICP technique. The mineral chemistry of plagioclase, pyroxene and biotite was performed at the Electronic Microprobe Laboratory at the Federal University of Rio Grande do Sul (UFRGS), using a CAMECA-SX50 microprobe, with 4 vertical WDS spectrometers and one EDS. The chemical standards utilized for calibration were $\mathrm{Si}-\mathrm{Anor} ; \mathrm{Ti}-\mathrm{TiO}_{2} ; \mathrm{Al}-\mathrm{Anor}$; $\mathrm{Fe}-\mathrm{MnHO} ; \mathrm{Mg}$ - MnHO; Mn-MnHO; $\mathrm{Ca}$ - Anor; $\mathrm{Na}$ - Jade; K Asbe; $\mathrm{Ni}-\mathrm{NiO}$; $\mathrm{Cr}-\mathrm{CrO}$. The acceleration stress, the current and point count times are $15 \mathrm{Kv}, 10 \mathrm{nA}$ and $30 \mathrm{x}$, respectively.

GEOLOGICAL SETTING The South Shetland Islands, where the Greenwich Island lies and where Hardy Point was the subject of the study (Fig.1), are included in the Antarctic context. Several studies performed on Greenwich Island and vicinity enabled the geological description of this region. Thus, Araya \& Hervé (1966), studying Media Luna Island (which lies $15 \mathrm{Km} \mathrm{SW}$ from the work area) determined that in this regions there are outcrops of basic to acid plutonic rocks (gabbros, diorites and tonalites), and this sequence was recognized on Greenwich Island by Parada (1987) and others. Araya \& Hervé (1966) continued to study Media Luna Island and determined that the plutonic rocks have a tholeiitic affinity with a volcanic sequence related to them. The only radiometric history of this island corresponds to a K-Ar age of 105 Ma carried out on a tonalite sample by Grikurov et al. (1970). The volcanic sequence can be considered pre-Albian. According to Keller e Fisk (1988), the subduction of the oceanic crust of Drake's plate toward the southeast under the Antarctic plate, has produced volcanism in the South Shetland Islands since the Mesozoic, and at the end of the Cenozoic the subduction and related volcanism practically ceased. In response to this, in the Bransfield Strait a young marginal basin appeared between the South Shetland Islands and the Antarctic Peninsula.

The separation of the sialic block which constitutes the South Shetland Islands, which was connected to the Antarctic Peninsula, began during the Pliocene, creating a tectonic rift filled with the waters of Bransfield Strait (Birkenmajer 1981) and with volcanic rocks (Keller and Fisk 1988).

PETROGRAPHY AND MINERAL CHEMISTRY Volcanic activity is marked by the extrusion of andesites with porphyritic texture and pilotaxitic and subophitic matrix. They consist of plagioclase zoned phenocrysts, locally diffuse and altered (epidote, carbonate), uralitic clinopyroxene, with small plagioclase inclusions, clinopyroxene, opaque minerals and interstitial glass. The subvolcanic facies is very similar in composition, but presenting amphibole formed after pyroxene (by uralitization) and biotite (in the matrix).

Intrusive activity is characterized by the intrusion of dioritic and granodioritic rocks, tonalites and granites, with a texture of predominantly unequal grains, altered plagioclase, uralitized clinopyroxene (the latter disappear into the granites), biotite which is locally chloritized, found mainly in the granodiorites and granites. Traces of apatite, zircon and titanite are seen.

The mineral chemistry shows that in volcanic rocks the plagioclase phenocrysts are normally zoned, with more calcic nuclei (An ${ }_{61-93}$ ), and more sodic borders $\left(\mathrm{An}_{58-79}\right)$. In the subvolcanic facies, the plagioclase crystals have a bytownite $\left(\mathrm{An}_{7483}\right)$ core and an andesine rim, and non zoned crystals are of labradorite $\mathrm{An}_{59}$. Biotite is poor in aluminum and occurs in the subvolcanic facies.

In the intrusive rocks the zoned plagioclase phenocrysts normally correspond to oligoclase $\mathrm{An}_{17}$ ranging to andesine $\mathrm{An}_{45-49}$ at the borders, and in the center, labradorite $\mathrm{An}_{51-59}$ ranging to anorthite $\mathrm{An}_{\text {93-94 }}$. The clinopyroxenes present a small compositional variation and occur as augite $\left(\mathrm{En}_{38-40} \mathrm{Fs}_{14-18} ; \mathrm{Wo}_{42-44}\right)$ and diopside $\left(\mathrm{En}_{37-38}\right.$ $\left.\mathrm{Fs}_{15-17} ; \mathrm{Wo}_{43-45}\right)$. The mica is biotite.

GEOCHEMISTRY The geochemical analyses of major elements, trace elements and REE, were performed at the Activation Laboratories, Canada, corresponding to: 7 sample of intrusive rocks; 1 dike; 1 of the border facies of the intrusive rocks; 2 subvolcanic and 3 volcanic. The results are presented in Table 1.

From the chemical standpoint, the sequence rocks are represented in a $\mathrm{Nb} / \mathrm{Y}$ versus $\mathrm{Zr} / \mathrm{TiO}_{2}$ diagram (Winchester \& Floyd 1977 - Fig. 2 ), with the volcanic rocks in the field of andesite ( 3 samples), the subvolcanic in the andesite ( 2 samples) and the intrusives in the field of diorite (5 samples) and monzonite (1 sample), the dike is dacitic with a gabbro border facies.

The behavior of the incompatible trace elements shows a positive correlation of $\mathrm{Zr}$ versus $\mathrm{Nb}$ and LREE (Fig. 3a,b). In both diagrams the intrusive rocks are the more evolved terms, as may also be observed in the correlation between $\mathrm{K}_{2} \mathrm{O}$ versus $\mathrm{Rb}$. In the $\mathrm{Al}_{2} \mathrm{O}_{3}$ $+\mathrm{Na}_{2} \mathrm{O}+\mathrm{K}_{2} \mathrm{O}$ versus $\mathrm{Al}_{2} \mathrm{O}_{3}+\mathrm{CaO}+\mathrm{Na}_{2} \mathrm{O}+\mathrm{K}_{2} \mathrm{O}$ diagram (Fig. 4 ) of Maniar \& Piccolli (1989) the rocks are metaluminous (except the dike).

In the AFM diagrams (Fig. 5a; Irvine \& Baragar 1971) and $\mathrm{Zr}$ versus $\mathrm{Y}$ (Fig. 5b, MacLean \& Barret 1993), all the analyzed samples present a typical calc-alkaline pattern with $\mathrm{TiO}_{2}<1 \%, \mathrm{Zr}$ mean of 68 $\mathrm{ppm}$ in the volcanic and $149 \mathrm{ppm}$ in the intrusive rocks, besides LREE enrichment.

The geochemical patterns indicate that these rocks probably originated from the same magma, which initial extrusion and later intrusion.

The REE normalized to chondrite (Nakamura 1977) (Fig. 6) shows a fractionation of the LREE with respect to the HREE, with a mean of $\mathrm{La} / \mathrm{Yb}_{\mathrm{N}}=4.528$ in the intrusives, 4.77 in the subvolcanics and 3.42 in the intermediary volcanics, with a LREE enrichment as compared with the HREEs; the intrusive rocks present a more evolved pattern and slight negative Eu anomaly (plagioclase fractionation). The LREE/ HREE ratio increases from the intermediary volcanics (mean 3.73) to the intrusive ones (mean 4.75). The Eu/Sm ratios $>0.244$ suggest a differentiation at a small depth.

When normalized to standard N-MORB (Sun \& McDonough 1989) in a multielement diagram (Fig. 7), a similar pattern is observed

1 - UNISINOS, Cx. Postal 275, CEP 93022-000, São Leopoldo/RS. E-mails: pilar@euler.unisinos.br, hansen@euler.unisinos.br, henrique@euler.unisinos.br, larissa.lima@zipmail.com.br, cris@euler.unisinos.br

2 - Instituto de Geociências, UFRGS, Av. Bento Gonçalves, 9500 - CEP: 91500-900 - Porto Alegre/RS, e-mail: adriane@if.ufrgs.br). 


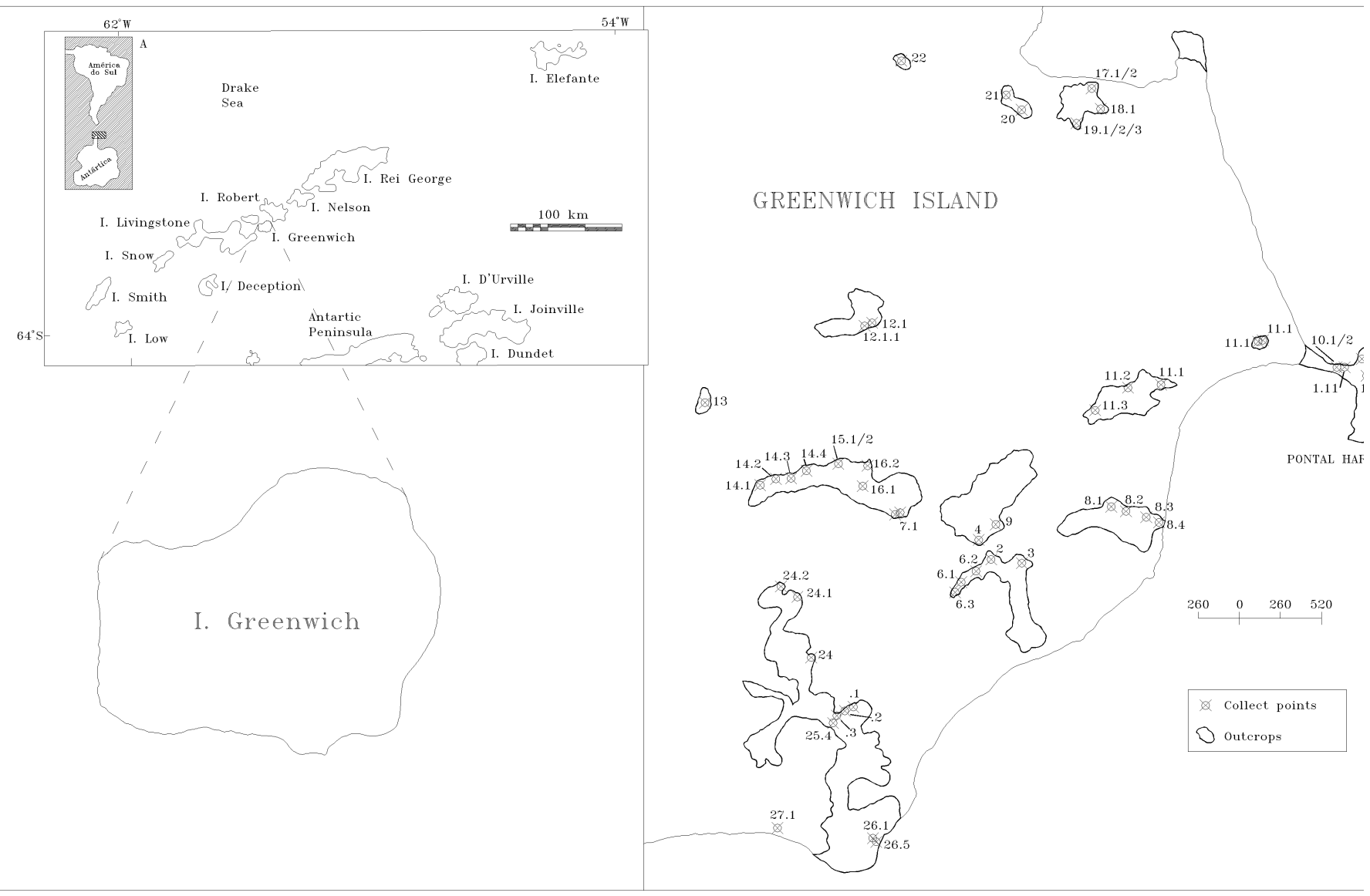

Figure 1 - localization map of the studied area and samples

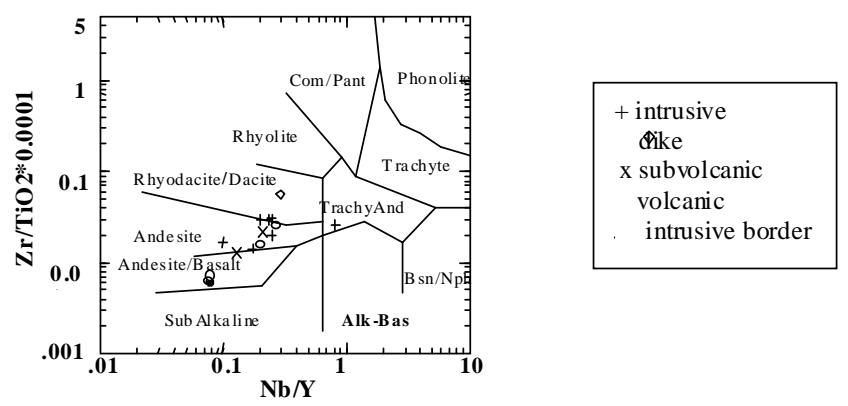

Figure $2-\mathrm{Zr} / \mathrm{TiO}_{2} \times \mathrm{Nb} / \mathrm{Y}$ diagram (Winchester \& Floyd, 1977)

in all groups, confirming the genetic relationship between all rocks. All samples show negative anomalies of $\mathrm{Nb}, \mathrm{P}, \mathrm{Ti}$, and also larger contents of LILE elements in relation to the HFSE, these characteristics being typical of orogenic rocks. It is important to stress the positive anomaly in $\mathrm{Ce}$, which may be related to the assimilation of Ce-enriched marine sediments.

TECTONIC SETTING The Antarctic Peninsula and the South Shetland Islands were formed due to the subduction of the Pacific Oceanic Crust under the Antarctic Continental Crust during the Mesozoic and Cenozoic; the Antarctic Peninsula is interpreted as a Mesozoic continental magmatic arc, and the South Shetland Islands as an island arc (Cretaceous - Lower Tertiary).

The South Shetland island arc is constituted by an ensialic basement of shales and deformed sedimentary rocks and is the result of magmatic activity during the Lower Cretaceous- Cenozoic. Lava flows with pyroclastic deposits, intrusive bodies in the form of small plugs, dikes, sills and basic plutons and intermediary rocks constitute the association related to the subduction process.

The age of the magmatism varies from 130 to $14 \mathrm{Ma}$ (Birkenmajer 1994) with renewed volcanic activity during the Quaternary (Smellie
A

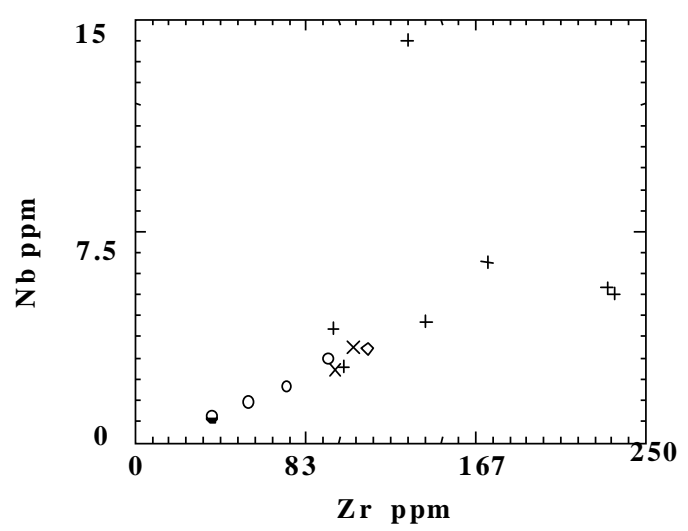

B

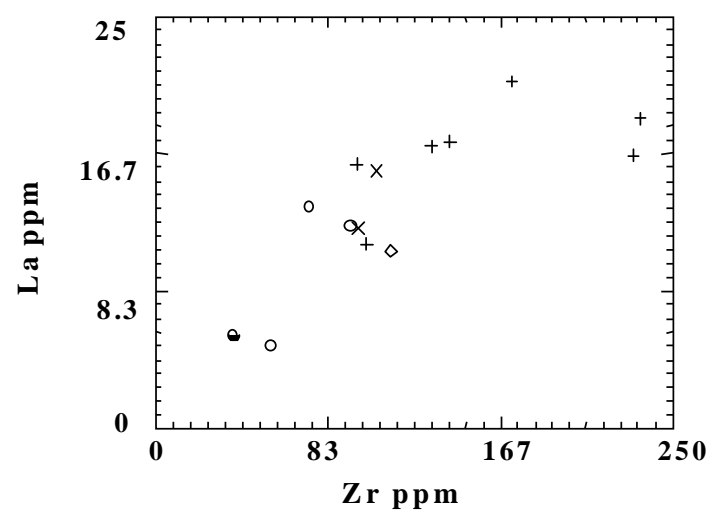

Figure $3-Z r$ versus $N b$ and La diagrams. Symbols as in figure 2. 
Table 1 - Geochemical analysis of major, trace elements. and REE.

\begin{tabular}{|c|c|c|c|c|c|c|c|c|c|c|c|c|c|c|}
\hline & dike & border & \multicolumn{7}{|c|}{ intrusive } & \multicolumn{2}{|c|}{ subvolcanic } & \multicolumn{3}{|c|}{ volcanic } \\
\hline Sample & $16.2 \mathrm{~A}$ & 26,3 & 20 & $\mathbf{7 , 3}$ & 8.1.1 & $8.2 \mathrm{~A}$ & 9,1 & 18,1 & 23,2 & 16.2B & 19,1 & 28,1 & 28,3 & 17.2A \\
\hline $\mathrm{SiO}_{2}$ & 76,3 & 53,33 & 63,7 & 57,9 & 57,99 & 57,26 & 57,5 & 63,4 & 56,7 & 54,36 & 56,2 & 68,6 & 53,95 & 55,99 \\
\hline $\mathrm{TiO}_{2}$ & 0,2 & 0,59 & 0,48 & 0,69 & 0,75 & 0,78 & 0,87 & 0,5 & 0,61 & 0,83 & 0,45 & 0,28 & 0,78 & 0,61 \\
\hline $\mathrm{Al}_{2} \mathrm{O}_{3}$ & 11,3 & 19,29 & 15,8 & 16 & 16,36 & 16,42 & 16,1 & 16,3 & 17,5 & 17,98 & 17,1 & 15,78 & 18,87 & 17,4 \\
\hline $\mathrm{Fe}_{2} \mathrm{O}_{3}$ & 1,31 & 7,8 & 5,16 & 8,09 & 7,26 & 7,59 & 7,66 & 5,25 & 8,45 & 8,08 & 6,7 & 3,41 & 8,49 & 7,46 \\
\hline $\mathrm{MnO}$ & 0,02 & 0,19 & 0,12 & 0,15 & 0,13 & 0,13 & 0,15 & 0,13 & 0,13 & 0,11 & 0,12 & 0,08 & 0,16 & 0,14 \\
\hline $\mathrm{MgO}$ & 0,17 & 4,74 & 2,04 & 3,3 & 3,07 & 3,21 & 3,28 & 2,05 & 3,62 & 3,24 & 4,78 & 1,61 & 4,57 & 3,89 \\
\hline $\mathrm{CaO}$ & 0,34 & 9,16 & 4,39 & 6,25 & 6,61 & 7,05 & 6,44 & 4,75 & 7,44 & 7,64 & 8,54 & 4,95 & 9,2 & 7,26 \\
\hline $\mathrm{Na}_{2} \mathrm{O}$ & 2,46 & 3,06 & 4,02 & 4,31 & 3,66 & 3,47 & 3,49 & 4,19 & 3,63 & 3,76 & 2,95 & 4,06 & 2,95 & 3,67 \\
\hline $\mathrm{K}_{2} \mathrm{O}$ & 5,91 & 0,36 & 2,06 & 1,21 & 1,79 & 1,59 & 1,83 & 1,75 & 0,68 & 0,6 & 1,05 & 0,6 & 0,2 & 1,05 \\
\hline $\mathrm{P}_{2} \mathrm{O}_{5}$ & 0,02 & 0,09 & 0,13 & 0,18 & 0,15 & 0,18 & 0,18 & 0,15 & 0,03 & 0,21 & 0,2 & 0,08 & 0,11 & 0,13 \\
\hline LOI & 0,39 & 1,44 & 1,17 & 0,49 & 0,79 & 0,74 & 1,15 & 1,53 & 0,98 & 1,44 & 1,96 & 1,02 & 0,59 & 1,49 \\
\hline Total & 98,2 & 100,1 & 99,7 & 98,5 & 98,55 & 98,41 & 98,6 & 100 & 99,7 & 98,24 & 100 & 100,5 & 99,87 & 98,57 \\
\hline $\mathrm{Ba}$ & 937 & 100,7 & 405 & 386 & 348,8 & 345,4 & 381 & 443 & 275 & 235 & 263 & 351 & 111,8 & 263 \\
\hline $\mathrm{Rb}$ & 109 & 7,46 & 53,8 & 28,3 & 51,68 & 46,58 & 54,3 & 44,9 & 53,8 & 13,87 & 25,3 & 14,4 & 3,36 & 27,44 \\
\hline $\mathrm{Sr}$ & 90,8 & 500,9 & 428 & 413 & 454,1 & 475,9 & 425 & 467 & 428 & 481,9 & 491 & 554 & 477,4 & 470,2 \\
\hline $\mathrm{Ta}$ & 0,46 & 0,982 & 0,36 & 0,29 & 0,403 & 0,381 & 0,44 & 0,34 & 0,19 & 0,245 & 0,21 & 0,204 & 0,106 & 0,231 \\
\hline $\mathrm{Nb}$ & 3,34 & 0,94 & 4,32 & 4,06 & 5,48 & 5,28 & 6,41 & 14,2 & 2,67 & 3,42 & 2,6 & 2 & 1,43 & 2,97 \\
\hline $\mathrm{Hf}$ & 3,78 & 1,09 & 4,14 & 2,9 & 6,36 & 6,4 & 5,13 & 3,74 & 3,15 & 3,02 & 2,91 & 2,11 & 1,61 & 2,68 \\
\hline $\mathrm{Zr}$ & 114 & 37,31 & 142 & 97,2 & 231,4 & 234,5 & 172 & 133 & 102 & 106,8 & 97,4 & 74,69 & 55,45 & 95,13 \\
\hline $\mathrm{Y}$ & 11,5 & 11,9 & 18,1 & 23,6 & 21,8 & 26,1 & 25,5 & 17,6 & 27 & 26,4 & 12,4 & 7,3 & 17,4 & 14,4 \\
\hline Th & 7184 & 0,378 & 7034 & 4049 & 6089 & 5344 & 7538 & 5530 & 9727 & 2931 & 5310 & 3025 & 0,63 & 4582 \\
\hline $\mathrm{La}$ & 10,8 & 5,63 & 17,4 & 16,1 & 16,58 & 18,81 & 21 & 17,1 & 11,3 & 15,58 & 12,1 & 13,42 & 5 & 12,25 \\
\hline $\mathrm{Ce}$ & 20,6 & 12,14 & 34,9 & 32,8 & 34,24 & 40,42 & 42,8 & 33,5 & 24,7 & 33,26 & 24,2 & 22,85 & 11,65 & 24,71 \\
\hline $\operatorname{Pr}$ & 2,02 & 1,476 & 3,6 & 3,63 & 3,729 & 4,442 & 4,71 & 3,42 & 3,05 & 3,762 & 2,52 & 2,084 & 1,424 & 2,634 \\
\hline $\mathrm{Nd}$ & 8,56 & 7,65 & 16,2 & 17,8 & 16,93 & 20,94 & 21,2 & 16,2 & 15,9 & 18,4 & 11,3 & 8,8 & 8,17 & 12,57 \\
\hline $\mathrm{Sm}$ & 1,98 & 2,08 & 3,62 & 4,52 & 4,13 & 5,06 & 5,04 & 3,54 & 4,64 & 4,79 & 2,69 & 1,78 & 2,35 & 2,84 \\
\hline $\mathrm{Eu}$ & 0,88 & 0,777 & 0,98 & 1,19 & 1,086 & 1,138 & 1,2 & 1,01 & 1,21 & 1,356 & 0,72 & 0,639 & 0,886 & 0,88 \\
\hline Gd & 1,94 & 2,11 & 3,66 & 4,58 & 4,34 & 4,97 & 5,25 & 3,68 & 4,39 & 4,86 & 2,65 & 1,81 & 2,73 & 2,86 \\
\hline $\mathrm{Tb}$ & 0,29 & 0,37 & 0,61 & 0,77 & 0,69 & 0,81 & 0,81 & 0,54 & 0,65 & 0,82 & 0,41 & 0,23 & 0,5 & 0,46 \\
\hline Dy & 1,84 & 2,08 & 3,13 & 4,28 & 3,94 & 4,51 & 4,52 & 3,09 & 4,96 & 4,62 & 2,15 & 1,34 & 3,13 & 2,71 \\
\hline Ho & 0,4 & 0,45 & 0,64 & 0,89 & 0,79 & 0,9 & 0,88 & 0,61 & 1,02 & 0,88 & 0,44 & 0,26 & 0,61 & 0,52 \\
\hline Er & 1,35 & 1,32 & 1,95 & 2,62 & 2,38 & 2,83 & 2,72 & 1,87 & 2,86 & 2,66 & 1,39 & 0,8 & 1,93 & 1,61 \\
\hline $\mathrm{Tm}$ & 0,22 & 0,176 & 0,29 & 0,37 & 0,352 & 0,398 & 0,37 & 0,28 & 0,42 & 0,391 & 0,21 & 0,13 & 0,275 & 0,224 \\
\hline $\mathrm{Yb}$ & 1,73 & 1,32 & 2,03 & 2,84 & 2,58 & 2,84 & 2,71 & 1,96 & 2,97 & 2,56 & 1,47 & 0,87 & 1,89 & 1,61 \\
\hline $\mathrm{Lu}$ & 0,3 & 0,232 & 0,34 & 0,42 & 0,41 & 0,445 & 0,43 & 0,33 & 0,47 & 0,418 & 0,22 & 0,163 & 0,314 & 0,282 \\
\hline
\end{tabular}

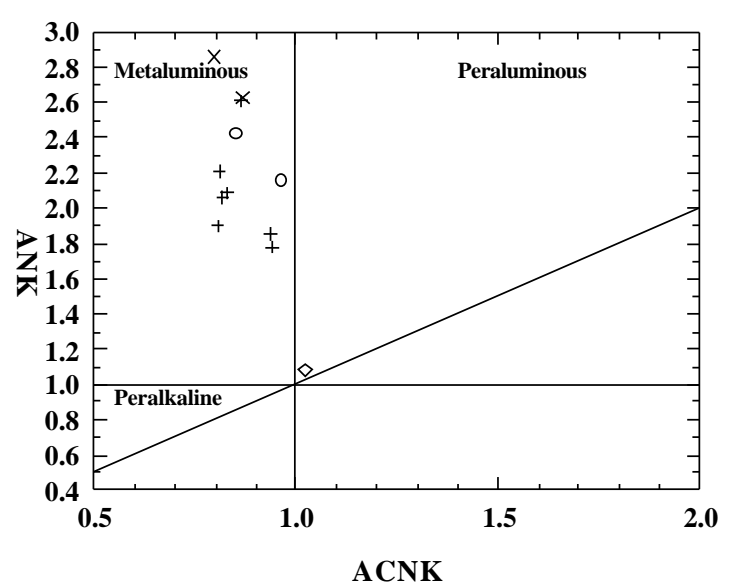

Figure 4 -ANK versus ACNK diagram (Maniar \& Piccoli, 1989.) Symbols as in Figure 2

et al. 1984). The strongest magmatic activity in the archipelago occurred during the Upper Jurassic - Lower Cretaceous. Several manifestations continued until the Tertiary (Smellie et al. 1984). During the Upper Cretaceous (probably since the Lower Cretaceous), an island arc tectonic regime may have occurred after the development of a magmatic arc.

The classic $\mathrm{Hf} / 3 \times \mathrm{Th} \times \mathrm{Nb} / 16$ diagram of Wood (1980, Fig. 8) and $\mathrm{FeO}_{\mathrm{t}}$ versus $\mathrm{MgO}$ versus $\mathrm{Al}_{2} \mathrm{O}_{3}$ of Pearce et al. (1977) enable the visualization that these rocks were generated in orogenic zones, with the participation of subduction. In order to provide greater precision regarding the type of tectonic setting, $\mathrm{Zr}$ versus Ti diagram was used (Pearce 1982, Fig. 9), and it was observed that these rocks were generated in a volcanic arc environment In magmatic arcs, it is typical to find HFSE depletion, owing to the fractionation of HFSE- rich phases in the initial magma. In the diagram of figure 7, the depletion of $\mathrm{Nb}, \mathrm{P}$ and Ti confirms the arc environment.

DISCUSSION AND CONCLUSIONS In the zone studied there is a sequence of volcanic, subvolcanic and intrusive rocks, with a basic to acid composition, originating from the same magma. The intrusive ones are the most evolved terms. This cogenetic character could be observed in the REE diagrams, in the spidergram and in the binary diagrams of trace and larger elements.

The negative anomalies of $\mathrm{Nb}, \mathrm{P}$ and $\mathrm{Ti}$ can be justified by the fact that these elements may have been retained in the subducted ocean plate, or, on the other hand, were retained in minerals such as rutile, ilmenite, titanite, which constitute the mantle during partial melting (Foley \& Wheller 1991). The negative anomaly of Ti in arc magmas results from the high $f \mathrm{O}_{2}$ in the subduction zone, ( Edwards et. al. 1994).

So, at Hardy Point and surroundings, an extrusive-plutonic event of calc-alkaline character took place, probably in Late Cretaceous emplaced in an island arc environment.

Acknowledgments To two referees of RBG for the critical review of the manuscript. 


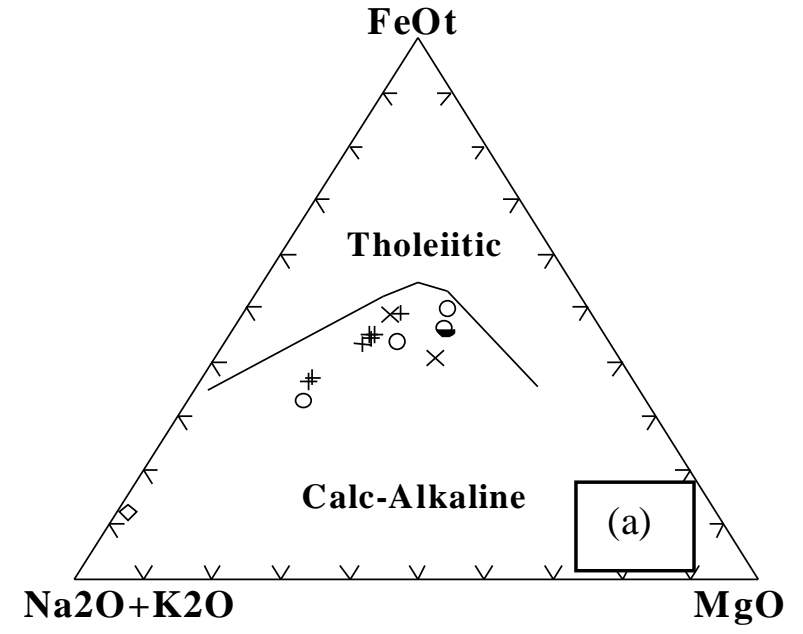

Figure $5 \mathrm{a}-\mathrm{FeO}_{\mathrm{t}}$ versus $\mathrm{Na}_{2} \mathrm{O}+\mathrm{K}_{2} \mathrm{O}$ versus $\mathrm{MgO}$ is according Irvine \& Baragar (1971). Symbols as in Figure 2.

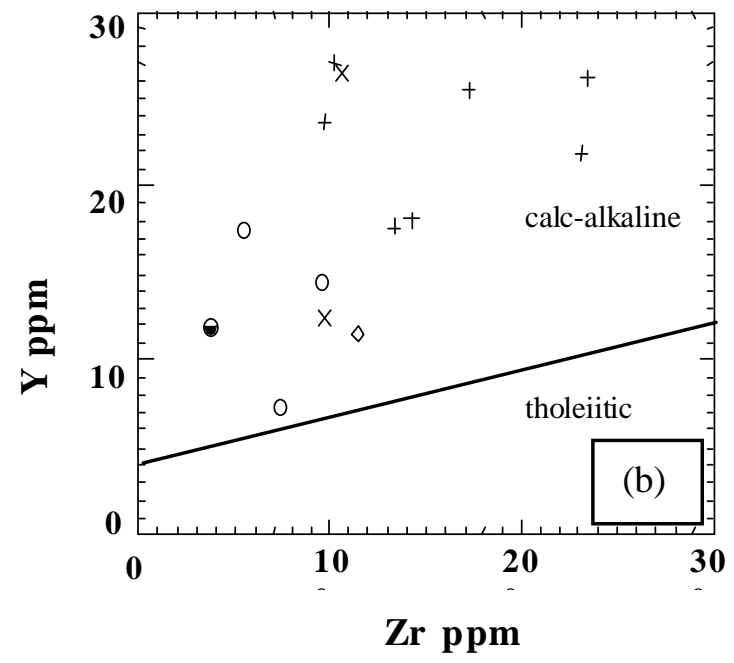

Figure 5b - Y versus Zr is according MacLean \& Barret (1993). Symbols as in Figure 2.

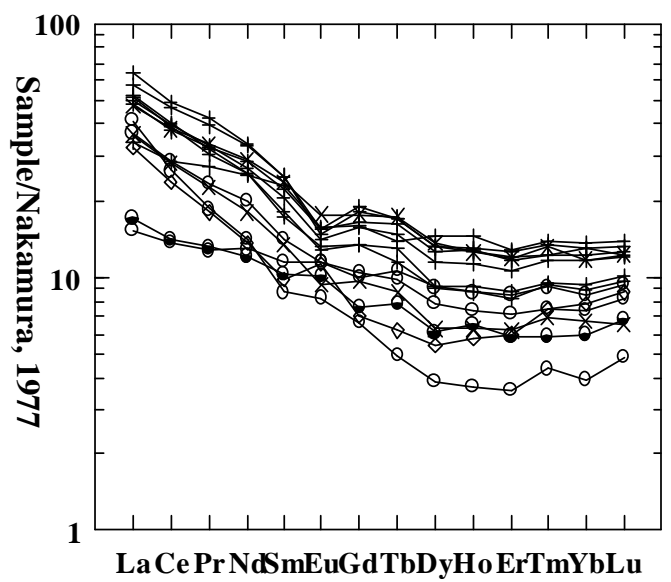

Figure 6 - Nakamura-normalized REE diagram. Symbols as in Figure 2

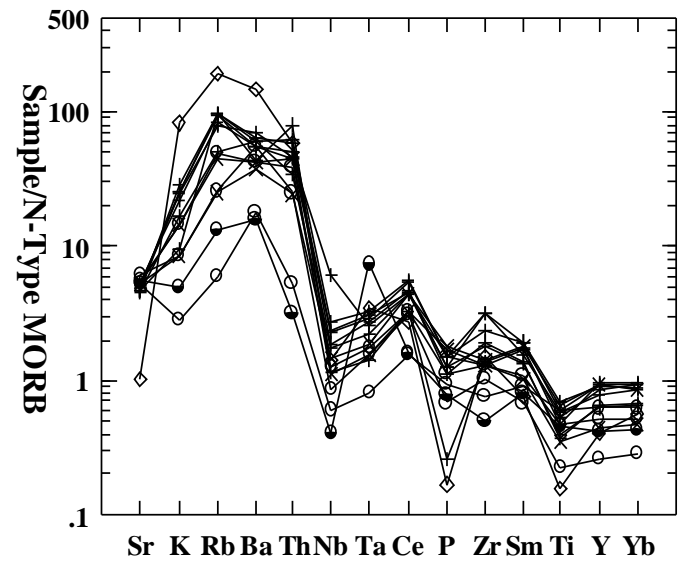

Figure 7 -Multi-element spider diagram. Normalising values are those of Sun \& McDonough (1989). Symbols as in Figure 2

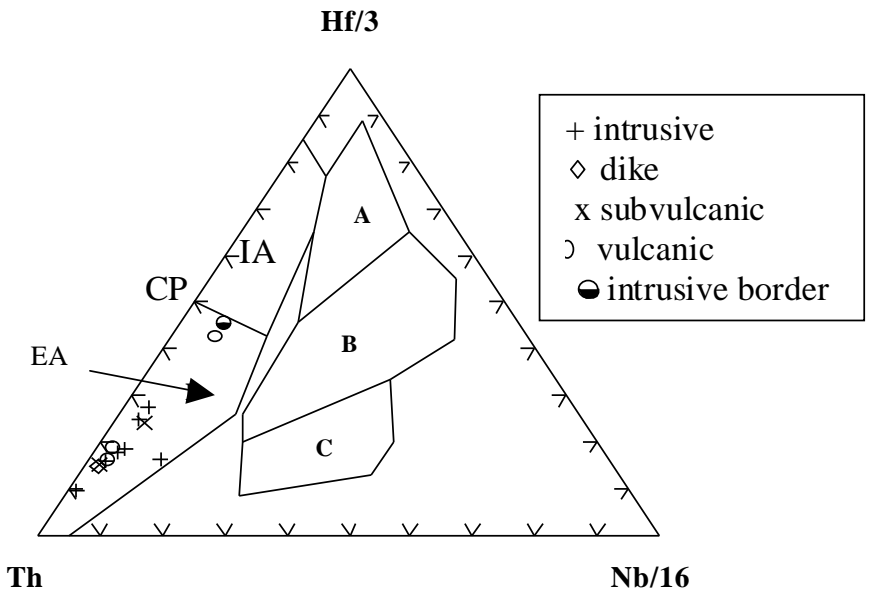

Figure 8 - Th-Hf-3-Nb/16 diagram after Wood (1980) showing distribution of studied lavas. $C P=$ convergent plate margin ( $E A$, evolved arc; IA, immature arc); $A=N$ - Morb; $B=E-M O R B ; C=$ within-plate.

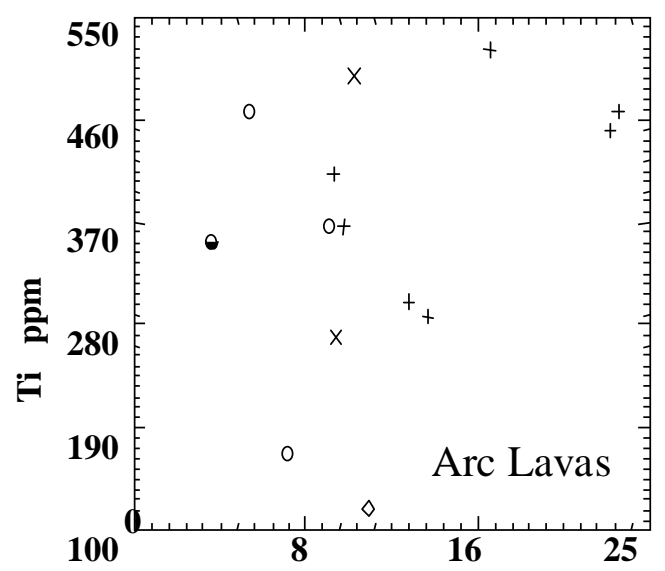

Zr ppm 


\section{References}

Araya R. \& Hervé F. 1966. Estudio geomorfológico y geológico en las Islas Shetland de Sur, Antártica. Instituto Antártico Chileno, Publicación, Santiago,. vol. 8, 76 p.

Birkenmajer K. 1981. Lithostratigraphy of Point Hennequim Group (Miocene volcanics an sediments) at King George Island (South Shetland Islands, Antarctica). Studia Geologica Polonica, Warszawa, 72:59-67.

Edwards C.M.H., Menzies M.A., Thirlwall M.F., Morrid J.D., Leeman W.P., Harmon R.S 1994. The transition to potassic alkaline volcanism in island arcs: the Ringgit-/beser Complex, east Java, Indonesia. J. Petrol., 35:173-193.

Foley S.F. \& Wheller G.E. 1980. Parallels in the origin of the geochemical signature of island arc volcanic and continental potassic igneous rocks: the role of residual titanates. Che. Geol., 85:1-18.

Grikurov G.E., Krylov A., Poljakov A., Covbun N. 1970. Vozrast gornych porod v severnoj casti Antarkticeskogo Poluostrova i na Juznych Setlandskich ostrovach (po dannyum kalij-argonovogo metoda). Inf. Biul. Sov. Antarkt. Eksp., 80:30-33.

Irvine T.N. \& Baragar W.R.A. 1971. A guide to the chemical classification of the common volcanic rocks. Can. J. Earth Sci., 8:523-48.

Keller R.A. \& Fisk M.R. 1988. Rifting and volcanism in the Bransfield Strait and South Shetland Islands, Antarct. J.U.S., Rev. 23, 102-104

MaClean W.H. \& Barret T.J. 1993. Lithochemical tecniques using immobile elements. Journal of Geochemical Exploration, 48:109-133.

Maniar P.D. \& Piccolli P.M. 1980. Tectonic discrimination of granitoids. Geological Society of America Bulletin, 101:635-643.

Miyashiro A. 1974. Volcanic rocks in island arcs and active continental margins. Am. Jour Sci., 274:321-355.

Nakamura N. 1977. Determination of REE, Ba, Fe, Mg, Na and $\mathrm{K}$ in carbonaceous and ordinary chondrites. Geochemica at Cosmochimica Acta, 38: 757-775.
Parada M.A., Orsini J.B., Hurtado A., Garrido I. 1987. Geologia y petrografia del complexo plutovolcánico de la Isla Media Luna, islas Shetland del Sur. Ser. Cient. INACH, 36:9-19.

Pearce J.A. 1982. Trace element characteristics of lavas from destructive plate boundaries. In: Andesites: orogenic andesites and related rocks, R.S. Thorpe (ed.), 525-48. Chichester: Wiley.

Peaarce T.H., GOorman B.E., Birkett T.C. 1977. The relationship between major element chemistry and tectonic environment of basic and intermediate volcanic rocks. Earth and Planetary Science Letters, 36:121-132.

Smelie J.L., Pankhurst R., Thomson M.R.A., Davies R. 1984. The geology of the South Shetland Islands: Stratigraphy, geochemistry and evolution. British Antarctic Survey Scientific Reports, v.87.

Sun S.S. \& McDonough W.F. 1989. Chemical and isotopic systematics of oceanic basalts: implications for mantle composition and process. In: Magmatism in the ocean basins. Geological Society, Special Publication, 42:313-345.

Winchester J.A. \& Floyd P.A. 1977. Geochemical discrimination of different magma series and their differentiation products using immobile elements. Chemical Geology, 20:325-343.

Wood D.A. 1980. The application of a Th-Hf-Ta diagram to problems of tectonomagmatic classification and to establishing the nature of crustal contamination of basaltic lavas of the British Tertiary volcanic province. Earth and Planetary Science Letters, 50:1130

Contribution IGC-018

Received January 26, 2000 Accepted for publication May 16, 2000 